\title{
TRANSFORMATIONAL LEADERSHIP AS A PREDICTOR TOWARDS JOB SATISFACTION AMONG FORM SIX TEACHERS IN SARAWAK
}

\author{
Siaw-Choon Loo' \\ Ying-Leh Ling ${ }^{2}$ \\ SMK Pending, Kuching, Sarawak, Malaysia1 \\ Mathematics, Science and Computer Department, Politeknik Kuching Sarawak, Malaysia2 \\ 2lingyingleh@gmail.com
}

First draft received: 03 May $2018 \quad$ Accepted: 31 June 2018 Final proof received: 20 August 2018

\begin{tabular}{|c|}
\hline $\begin{array}{l}\text { Abstract } \\
\text { This quantitative study was conducted to identify the influence of transformational leadership as a } \\
\text { predictor of job satisfaction among Form Six teachers. A total of } 148 \text { Form Six teachers from Kuching, } \\
\text { Sarawak through a random sampling technique were identified as respondents of the study. Data was } \\
\text { collected by distributing questionnaires to the respondents. The questionnaire used was adapted from } \\
\text { the previous researchers' questionnaires. The findings show that the dimensions of individual } \\
\text { consideration, charisma, and motivation in transformational leadership have a significant effect on job } \\
\text { satisfaction among the teachers. Based on the findings obtained, the two-ways relations between the } \\
\text { middle leaders and teachers need to be improved by adopting an open approach and working to } \\
\text { understand the work-related problems. } \\
\text { Keywords: Transformational leadership; job satisfaction; form six teachers }\end{array}$ \\
\hline $\begin{array}{l}\text { To cite this paper (in APA style): } \\
\text { Loo, S-C., \& Ling, Y-L. (2018). Transformational leadership as a predictor towards job satisfaction among } \\
\text { form six teachers in Sarawak. International Journal of Education, } 11(1), 1-5 . \text { doi: } \\
\text { http://dx.doi.org/10.17509/ije.v11i1.11087 }\end{array}$ \\
\hline
\end{tabular}

\section{INTRODUCTION}

Principal's leadership and academic success at school should not be seen as two separate things. This is clearly evidenced by previous studies which state the relationship between the quality of school leaders and academic success (Hallinger, 2007; Ibrahim, Ghavifekr, Ling, Siraj, \& Azeez, 2014; Aydin, Savier, \& Uysal, 2013; Leithwood \& Mascall, 2008). In fact, leadership style among school leaders is also a catalyst that shapes the success of a leader's school with his/her management team members. However, it is important to note that school leaders are not the only leading individuals who make decisions about improving school effectiveness (Greenwood, 2011). Furthermore, more studies have been carried out emphasizing the important role of middle leaders in ensuring the balance of existing educational system structures and managing educational changes (Ling, Abdul Ghani, \& Fairuz, 2015; Earley \& Fletchel-Campbell, 1989).

The transformational leadership theory was founded by Burns (1978) and subsequently purified by Bass (1985). It is a process where leaders and followers work together to achieve higher levels of motivation and morals (Burns, 1978). This leadership style can change perceptions and values as well as increasing the motivations and aspirations of their followers. The transformational approach emphasizes the personality, character, and capabilities of leaders making changes by example, vision, and goals. Transformational leaders can influence individuals to change, strive, and be willing to be led by the organization in particular because the practice of transformational leadership can influence followers to admire, respect, and trust them (Gorton, Alston, \& Snowden, 2006; Northouse, 2012; Yukl, 2006). At the same time, transformational leadership has a positive impact on teachers' motivation, professional development and contributes to the change of school culture and educational change (Kruger, Witziers, \& Sleegers, 2007). A study on the influence of transformational leadership on job satisfaction is much carried out either within or outside the country. Previous studies have shown that transformational leadership affects the commitment of workers (Raman, Mey, Don, David, \& Khalid, 2015; Khasawneh, Omari, \& Abu-Tineh, 2012; Liu, 2015) and the existence of organizational improvement culture Work (Chen, 2014).

Castanheira and Costa (2011) have listed three transformational leadership functions, namely: (1) the leader serves the needs of others with genuineness, to 
empower them and inspire followers to achieve success; (2) the leader leads charismatically; is visionary; inculcates trust, self-confidence and pride to work with them; (3) through intellectual stimulation, a leader's followers will be in caliber with their leader. There are four dimensions of leadership. The dimension of charisma emphasizes the transformation of the leaders that always take into account the needs of others, not abuse power, and set a challenging goal for their followers (Popper, Mayseless, \& Castelnovo, 2000). Next, the dimension of individual judgment also sees leaders as mentors who provide feedback and adjust the needs of staff with the organization's mission. In this case, leaders provide different services based on their interests and knowledge (Shin \& Zhou, 2003) with the aim of giving individuals the chance to achieve higher goals. For intellectual stimulation dimensions, Popper, Mayseless, and Castelnovo (2000) also said a leader should make efforts to stimulate his/her followers to be more creative and innovative. A transformational leader helps his/her followers identify problems and challenges and deal with their abilities (Bono \& Judge, 2004). Finally, inspiration is also important to increase productivity. Northouse (2004) finds transformational leaders communicate with high expectations with their followers, inspiring them by motivating their followers to commit and share the same vision of the organization. Leaders use symbols and emotional appeals so their followers strive toward achieving more than they want to achieve. Team spirit can then be enhanced through transformational leadership.

On the other hand, the issue of job satisfaction needs to be thoroughly addressed. Job satisfaction is the level that the employee feels when work can be done well (Armstrong, 2006; Robbins, 2003). Armstrong (2006) sees job satisfaction as a person's behaviour and feelings toward his work. In that regard, Lee and Chan (1996) have defined job satisfaction as a positive emotional or emotional state as a result of a person's work or experience. It is also viewed as an important attribute that every organization wishes to achieve as there is significant evidence of dissatisfaction in the work organization (Oshagbemi, 2003; Robbins, 2003). For example, Lichenstein (1998) has shown job satisfaction as an important factor in determining high turnover rates in work. This is also explained by Ramayah (2001) where satisfaction depends on the extent to which the job can meet one's needs.

In Malaysia, Form Six Education has started operating in government secondary schools since fifty years ago. Pupils who have graduated from upper secondary education and have completed the Malaysian Certificate of Education (MCE) or Sijil Pelajaran Malaysia (SPM) examination, are eligible to be offered for post-secondary education i.e. Form Six, if they meet the general terms and specialty for the course, for three terms. There are two streams offered for the Form Six education, namely Social Science (Humanities and Religious) and Science stream. Form Six is the educational route for SPM students to develop their talents and creativity to become a high-impact universal young generation. They eventually bring success to the country as well as qualifying for international standards.

In the secondary school context, the Senior Assistant (Penolong Kanan) is a middle leader who plays an important role in completing the task entrusted in leadership co-operation (Jayne, 1996). As middle leaders, they need to be able to mobilize their followers, the teachers under their leadership to work together to address the changes they face (Ling et al., 2015). Hence, they need to be concerned and have a good and approachable relationship with their teachers by involving employees in the decision-making process towards achieving goals together. Indirectly, this will raise the level of teachers' job satisfaction and performance. Thus, teachers' satisfaction will increase when their needs are met and at the same time the leaders will get satisfaction when the teachers manage to achieve high productivity (Jaafar, 2007).

Rebranding Form Six is one of the initiatives in the Malaysian Education Development Plan (PPPM) 20132015 to ensure that the status of Form Six is equivalent to Pre-University education. Rebranding is done due to the continuing decline in the percentage of students admitted to Form Six studies (Tang \& Tham, 2014) and the need to strengthen Form Six education and change the public perception of Form Six education (Ministry of Education, 2016). The rebranding has emphasized the increasingly important role of Senior Assistant in assisting the administration of school leaders. However, the reality is that the Form Six Senior Assistant is too productive to neglect the real needs of teachers. The absence of flexibility in the implementation of work, overly bound by the established bureaucracy, disciplinary action or low performance scores has caused teachers to feel depressed in discharging their responsibilities. The question is: Can Form Six Senior Assistants play a role to increase the satisfaction of Form Six teachers? Thus, researchers feel that there is a need to investigate the influence of transformational leadership in middle leaders on job satisfaction among Form Six teachers. Specifically, the objective of this study is to determine whether the dimensions of transformational leadership among Form Six Senior Assistant are significant predictors of the satisfaction of Form Six teachers.

\section{RESEARCH METHODOLOGY}

This study uses quantitative approaches through the collection and analysis of numerical data to clarify the events to be investigated and to test the associated hypotheses (Gay, Mills, \& Air, 2012). In this study, the study design is used for reporting the level of transformational leadership among the Form Six Senior Assistant and level of job satisfaction among teachers of Sixth Form.

The total number of Form Six teachers was identified from nine secondary schools located at Kuching city is 229. In this study, a random sampling technique was used, involving 148 Form Six teachers. The instrument used in this study is a set of questionnaires consisting of three parts. Part $A$ refers to the background of respondents. Part $B$ involves 16 
items adapted from Nazri (2008) to get respondent's perception about transformational leadership practicing by Senior Assistant. There are four sub-dimensions in Part B, namely charisma, individual consideration, intellectual stimulation, and inspirational motivation which was adapted from Herzberg's Job Satisfaction Inventory by Mohammad Aziz et al. (2015). There are 24 items used to measure eight dimensions in the job satisfaction among Form Six teachers. Eight dimensions are involved in Part $\mathrm{C}$, consisting of the work itself, achievements, recognition, responsibilities, working environment, interpersonal relationships, administrative policies, and incentives. Five-point Likert scale has been used in this questionnaire, where the scale is 1-Strongly Disagree to 5-Strongly Agree.

A pilot study was conducted towards twenty Form Six teachers randomly selected from secondary schools in Kota Samarahan to identify the suitability and reliability of questionnaires used. The reliability test has shown that all items in the questionnaire have achieved the value of reliability between .64 and .92 . In order to conduct a real study, the approval from the Planning and Research Division, Ministry of Education has been obtained. Furthermore, researchers have obtained Table 1 Distribution of respondents permission from the Sarawak Education Department and Kuching District Education Office before the application for permission was submitted to the Principal of the school to distribute the questionnaire to the respondents. All completed questionnaires were returned to the researchers through a school representative with a return rate of 86 percent, of which is only 162 sets. Of the total delivered, 148 were processed for the next analysis purpose.

\section{RESEARCH FINDINGS}

\section{Respondent Profile}

This study involved 148 respondents consisting of 44 male respondents and 104 female respondents. The majority of respondents were in the age range of 46 years and above, which was 53 percent. A total of 116 respondents or 78 percent held a bachelor's degree. Furthermore, the majority respondents had work experience of 16 to 20 years with a total of 41 persons or 28 percent. The findings also show that 56 respondents had monthly income, including allowances of between RM7001 and RM8500, with a rate of 38 percent.

\begin{tabular}{|c|c|c|}
\hline Respondent Demography & Frequency & Percentage \\
\hline \multicolumn{3}{|l|}{ Gender } \\
\hline Male & 44 & 30 \\
\hline Female & 104 & 70 \\
\hline \multicolumn{3}{|l|}{ Age } \\
\hline $25-30$ years & 1 & 1 \\
\hline $31-35$ years & 6 & 4 \\
\hline $36-40$ years & 30 & 20 \\
\hline $41-45$ years & 32 & 27 \\
\hline 46 years and above & 79 & 53 \\
\hline \multicolumn{3}{|l|}{ Education Qualification } \\
\hline Bachelor degree & 116 & 78 \\
\hline Master degree & 31 & 21 \\
\hline Doctor of Philosophy & 1 & 1 \\
\hline \multicolumn{3}{|l|}{ Years of Service } \\
\hline $6-10$ years & 9 & 6 \\
\hline $11-15$ years & 27 & 18 \\
\hline $16-20$ years & 41 & 28 \\
\hline $21-25$ years & 37 & 25 \\
\hline 26 years and above & 34 & 23 \\
\hline \multicolumn{3}{|l|}{ Monthly Salary } \\
\hline RM 4001 - RM 5500 & 12 & 8 \\
\hline RM 5501 - RM 7000 & 46 & 31 \\
\hline RM 7001 - RM 8500 & 56 & 38 \\
\hline RM 8501 - RM 10000 & 29 & 20 \\
\hline RM 10001 and above & 5 & 3 \\
\hline
\end{tabular}

Multiple linear regression analysis was conducted to investigate whether transformational leadership among the Senior Assistant was a significant predictor towards job satisfaction among Form Six teachers. 
Table 2 Coefficient $\beta$ for the influence of transformational leadership on job satisfaction

\begin{tabular}{lccc}
\hline & \multicolumn{2}{c}{ Dependent Variable: Job Satisfaction $(\boldsymbol{\beta})$} \\
\hline $\begin{array}{l}\text { Independent Variable: Transformational } \\
\text { Leadership }\end{array}$ & Model 1 & Model 2 & Model 3 \\
\hline Charismatic & $.31^{*}$ & .07 & .09 \\
Individual Consideration & & $.31^{*}$ & .16 \\
Inspiration motivation & & & $.34^{*}$ \\
\hline $\mathrm{R}$ & .31 & .36 & .40 \\
$\mathrm{R}^{2}$ & .10 & .13 & .16 \\
Adjusted $\mathrm{R}^{2}$ & .09 & .12 & .15 \\
F Value & $15.9^{*}$ & $11.1^{*}$ & $9.30^{*}$ \\
\hline
\end{tabular}

Note: * Significant on the level of $p<.05$

Based on Table 2, the results in Model 1 showed the dimension of charisma $(\beta=.31, t=3.99, p<.05)$ contributed significantly 9.8 percent $(r=.31)$ to job satisfaction $[F(1,146)=15.9, p<.05]$. In model 2 , the significant $\beta$ value for individual consideration $(\beta=.31$, $t=2.40, \quad p<.05)$ shows that this dimension had a significant influence on the job satisfaction. The insignificant results for charisma dimensions $(\beta=.07$, $t=.53, p<.05$ ) also indicate that charisma is not a significant predictor of job satisfaction within Model 2. The results of the analysis also found that both the dimension of charisma and individual considerations accounted for 13.3 percent $(r=.36)$ variance changes in job satisfaction $[F(2,145)=11.1, p<.05]$. Furthermore, in model 3 , significant $\beta$ values for inspirational motivation dimensions $(\beta=.34, t=2.26, \quad p>.05)$ show significant influence on job satisfaction criteria. While the insignificant decision for the charisma dimensions $(\beta=.10, \quad t=.63, \quad p>.05)$ and individual judgment dimensions $(\beta=.16, \quad t=1.13, \quad p>.05)$ have shown charisma and individual considerations not significant predictor to job satisfaction.

The results of the analysis have shown significantly that three dimensions of individual judgment, charisma, and inspirational motivation account for 16.2 percent $(r=.40)$ variance changes in job satisfaction $[F(3,144)=9.3, p<.05]$. Therefore, the three dimensional predictors of charisma, individual considerations, and intellectual motivation included in the regression model at $p<.05$ are factors for job satisfaction among those respondents. The findings of this study support the previous studies' findings (Ghanbari \& Eskandar, 2014, Long, Yusof, Kwang, \& Heng, 2014) where the individual judgment dimension is a predictor of teacher job satisfaction. In addition, Khalip et al. (2014) explained individual considerations emphasizing the leaders' concerns over development needs and increasing the potential of their followers. The findings also reinforce the study of Ling and Ibrahim (2013) showing intrinsic motivation as a motivating process for followers to be more committed and have the same vision with the organization.

\section{CONCLUSION}

Charismatic leaders need to be optimistic about the vision and mission of the organization and are willing to sacrifice for the benefit of the organization. They are also able to motivate their followers to perform with dedication and eager to work as well as having job satisfaction. This study found that transformational leadership among middle leaders should be enhanced so that job satisfaction can remain at a maximum level. The findings of this study are also used as a reference for education managers in general. Specifically, this study finding can assist the Malaysian Education Ministry in designing and planning training programs and seminars for the Sixth Former Senior Assistant, in particular relating to the concepts and practices of leadership, organization, and decision making in schools.

\section{REFERENCES}

Armstrong, M. (2006). A handbook of human resource management practice, $\left(10^{\text {th }}\right.$ ed.). London: Kogan Page Publishing.

Aydin, A., Savier, Y., \& Uysal, S. (2013). The effect of school principals' leadership styles on teachers' organizational commitment and job satisfaction. Educational Sciences: Theory and Practice, 13(2), 805-811.

Bass, B. M. (1985). Leadership and performance beyond expectation. New York: Free Press.

Bono, J. E., \& Judge, T. A. (2004). Personality and transformational and transactional leadership: a meta-analysis. Journal of applied psychology, 89(5), 901.

Burns, J. (1978). Leadership. New York: Harper \& Row.

Castanheira, P., \& Costa, J. A. (2011). In search of transformational leadership: A (Meta) analysis focused on the Portuguese reality. Procedia-Social and Behavioral Sciences, 15, 2012-2015.

Chen, S. P. (2014). Pengaruh kesejahteraan di tempat kerja sebagai pengantara terhadap hubungan antara kepimpinan transformasi pengetua dan budaya dengan penambahbaikan organisasi sekolah utara Semenanjung Malaysia (Unpublished doctoral dissertation). Universiti Sains Malaysia, Malaysia. 
Earley, P., \& Fletcher-Campbell, F. (1989). Managing school departments and faculties: towards better practice. Educational Research, 31(2), 98-112.

Ghanbari, S., \& Eskandari, A. (2014). Transformational leadership, job satisfaction, and organizational innovation. International Journal of Management Perspective, 1(4), 81-94.

Gorton, R., Alston, J., \& Snowden, P. (2006). School leadership and administration: Important concepts, case studies and simulations. Open University Press. The McGraw-Hill.

Greenwood, J.Y. (2011). African American teacher leaders: Selections, supports, barriers. (Unpublished doctoral dissertation). Auburn University, Alabama.

Hallinger, P. (2007). Leadership for Learning: Reflections on the practices of instructional and transformational leadership. Paper presented at Seminar at East Asia University.

Ibrahim, M. S., Ghavifekr, S., Ling, S., Siraj, S., \& Azeez, M. I. K. (2014). Can transformational leadership influence on teachers' commitment towards organizational, teaching profesion and students learning? A quantitative analysis. Asia Pacific Educ. Rev., 15, 177-190. http://dx.doi.org/10.1007/s12564-013-9308-3

Jaafar, M. (2007). Kelakuan organisasi. Petaling Jaya: Leeds Publication.

Jayne, E. (1996). Developing more effective primary deputy (or associate) heads. Educational Management \& Administration, 24(3), 317-326.

Kementerian Pendidikan Malaysia. (2016). Garis Panduan Pengurusan Tingkatan Enam (GPPT6). Bahagian Pengurusan Sekolah Harian, Putrajaya.

Khalip, M., Hamidah, Y., Jamal, N. Y., \& Suriani, A. H. (2014). Kepimpinan transformasional pengetua: Perbandingan antara sekolah menengah awam dan swasta cemerlang. Management Research Journal, 3, 120-139.

Khasawneh, S., Omari, A., \& Abu-Tineh, A. M. (2012). The relationship between transformational leadership and organizational commitment: The case for vocational teachers in Jordan. Educational Management Administration \& Leadership, 40(4), 494-508.

Krüger, M. L., Witziers, B., \& Sleegers, P. (2007). The impact of school leadership on school level factors: Validation of a causal model. School Effectiveness and School Improvement, 18(1), 120.

Lee, K. C., \& Chan K. W. (1996). Job satisfaction and conflict among technical employees in selected Malaysian engineering firms. Journal of Management, 15, 45-62.

Leithwood, K. A., \& Mascall, B. (2008). Collective leadership effects on student achievement. Educational Administration Quarterly, 44(4), 529561.

Lichenstien, R. L. (1998). The job satisfaction and retention of physicians in organized setting: $A$ literature review. Med Care Rev, 41, 139- 179.
Ling, S. L. M., \& Ibrahim, M. S. (2013). Transformational leadership and teacher commitment in secondary schools of Sarawak. International Journal of Independent Research and Studies, 2(2), 51-65.

Ling, Y. L., Abdullah, K. A. G., \& Ismail, F. (2015). Feedback environment and job motivation among middle leaders of educational organizations. Journal of Education and Training, 3(1), 90-105.

Liu, P. (2015). Motivating teachers' commitment to change through transformational school leadership in Chinese urban upper secondary schools. Journal of Educational Administration, 53(6), 735754.

Long, C. S., Yusof, W. M. M., Kwang, T. O., \& Heng, L. $\mathrm{H}$. (2014). The impact of transformational leadership style on job satisfaction. World Applied Sciences Journal, 29(1), 117-124 doi: 10.5829/idosi.wasj.2014.29.01.1521

Shah, M. A., Jais, S. M., Sofian, S., Mustafa, M. B., Tarmalinggam, J. N., \& Tan, E. S. (2015). Pembinaan, kesahan dan kebolehpercayaan inventori kepuasan kerja Herzberg (IKKH). Jurnal Bitara Edisi Khas (Psikologi Kaunseling), 8, 45 63.

Nazri, M. (2008). Amalan kepimpinan transformasi guru besar dan pengetua di dua buah sekolah daerah Batu Pahat, Johor. (Unpublished degree's dissertation). Universiti Teknologi Malaysia.

Northouse, P. G. (2012). Leadership: Theory and practice. New York: Sage publications.

Oshagbemi, T. (2003). Personal correlates of job satisfaction: empirical evidence from UK universities. International Journal of Social Economics, 30, 1210-1232.

Popper, M., Mayseless, O., \& Castelnovo, O. (2000). Transformational leadership and attachment. The Leadership Quarterly, 11(2), 267-289.

Ramayah, T., (2001). Job satisfaction: Empirical evidence for alternative to JDI. National Decision Science Conferences, San Fransisco.

Raman, A., Mey, C. H., Don, Y., Daud, Y., \& Khalid, R. (2015). Relationship between principals' transformational leadership style and secondary school teachers' commitment. Asian Social Science, 11(15), 221.

Robbins, S.P. (2003). Organisational behaviour (10th ed). San Diego: Prentice Hall.

Gay, L., Mills, G. \& Airasian, P. (2012). Educational research: Competencies for analysis and applications. (10th ed.). Pearson Education, Inc.

Shin, S. J., \& Zhou, J. (2003). Transformational leadership, conservation, and creativity: Evidence from Korea. Academy of management Journal, 46(6), 703-714.

Tang, K. N., \& Tham, Y. M. (2014). Penjenamaan semula sistem pentadbiran Tingkatan Enam: Satu kajian kes. Jurnal Kepimpinan Pendidikan 1(2), 52-60.

Yukl, G. (2006). Leadership in organizations (6th ed.). Upper Saddle River, NJ: Prentice Hall. 